\title{
EFFECT OF SOME AZOSPIRILLUM STRAINS AS A PARTIAL REPLACEMENT OF INORGANIC N FERTILIZERS ON YIELD AND QUALITY OF SUPERIOR GRAPEVINES
}

\author{
F. F. Ahmed ${ }^{(1)}$, O. F. Dakhly ${ }^{(2)}$, M.A.M. Abada ${ }^{(3)}$ and M. Kh. Uwakiem ${ }^{(3)}$ \\ (1) Hort. Dept., Fac. of Agric., Minia Univ., Egypt. \\ (2) Genetics. Dept., Fac. of Agric., Minia Univ., Egypt. \\ (3) Viticulture Res. Dept. Hort. Res. Inst. ARC, Giza, Egypt.
}

Received: Oct. 16, 2017

Accepted: Oct. 30,2017

\begin{abstract}
About 91 mutants were obtained from exposing Azospirillum brasilense to different concentrations of Acriflavine mutagen and different time exposure. Out of those three new N microbial strains namely Methionineless, Threonineless and Tyrosineless were tested on Superior grapevines after their showed highest growth on artificial media. Superior grapevines were supplied with these microbial strains at 5 to $20 \mathrm{ml} / \mathrm{vine}$ and three slow release fertilizers (Methylene urea, Sulphur coated urea and urea formaldehyde) at 25 to $75 \%$ as partial replacement of the fast release $N$ fertilizer namely ammonium nitrate during 2015 and 2016 seasons.

Supplying Superior grapevines with $N$ through 50 to $75 \%$ inorganic $N+25$ to $50 \%$ slow release $N$ fertilizers (Methylene urea, Sulphur coated urea and urea formaldehyde) + bacteria strains (Methionineless, Threonineless and Tyrosineless) at 5 to $10 \mathrm{ml} /$ vine proved to be very effective in stimulating all growth traits, leaf pigments and nutrients, berry setting $\%$, yield and quality of the berries relative to using $N$ as $100 \%$ mineral $N$ or when mineral $N$ was added at $25 \%$. An obvious reduction was observed on both nitrate and nitrite in the juice, with reducing percentages of mineral $N$ from 100 to $25 \%$ as well as increasing percentages of the three release $N$ fertilizers from 25 to $75 \%$ and the three bacterial strains from 5 to $20 \mathrm{ml} / \mathrm{vine}$. The best bacterial strains in this respect were Methionineless, Theronineless and Tyrosineless, in ascending order. The best slow release fertilizer was methylene urea followed by sulphur coated urea.

Amending Superior grapevines with $N$ as $50 \%$ inorganic $N$ (ammonium nitrate) $+50 \%$ slow release $\mathrm{N}$ fertilizer (methylene urea) + Tyrosineless at $10 \mathrm{ml} / \mathrm{vine}$ was responsible for promoting yield and fruit quality.
\end{abstract}

Key words: Fast and slow release $N$ fertilizers, bacterial strains, growth, yield, berries quality, Superior grapevines.

\section{INTRODUCTION}

Superior grapevines cv. is considered a prime and favourite grape cv successfully grown under Egypt conditions. Due to its early in ripening season cv. it has a greater potentially for export to foreign markets. For enhancing export efficiency and protecting our environment from pollution, it is reliable to adjust the amount of mineral $\mathrm{N}$.

Nitrogen fertilization is considered an important and limiting factor for fruiting of different grapevine cvs. Using $\mathrm{N}$ in the form of mineral at higher amounts causes severe damage to environment and could result in enhancing growth of the vines at the expense of fruiting status.

Nowadays, slow release $\mathrm{N}$ fertilizers, plant wastes and biofertilizers were used as partial replacement of mineral $\mathrm{N}$ fertilizers in most fruit orchards. In organic farming system microorganisms were used as biological for sustainable agriculture (Wani and Lee, 1995). Application of chemical fertilizers in the fruit orchards causes some problems especially for exportation. It is well known that nitrogenous fertilizers are lost via 
nitrate reduction, denitrification and ammonia volatilization. Moreover, some nitrogenous fertilizers can be leached to the surface and underground water causing environmental pollution (Attia, 1990). Mahendran and Chandramani, (1998) reported that dual inoculation of plants with the above mentioned microorganisms increased soil availability of N, P and K.

The economical point account, and the high prices of chemical fertilizers may increase the production costs. Therefore, the use of biofertilizers and organic manures of particular interest to avoid the previously mentioned problems. Biofertilizers application with a half dose of chemical nitrogen fertilizer provided to be an efficient tool in increasing the availability of nutrients in soil as well as growth performance and yield of cultivated crops is improved. Several investigators indicated that inoculation with Azotobacter and Azospirillum improved growth and yield of horticultural crop (Kannaiyan, 2002).

At one time, it was thought that the counterpart of Azospirillum, which is found in legumes had been found for cereals, and by exploiting the capabilities of Azospirillum Sp. it would be possible to supply nitrogen to crops of economic importance (Klingmuller, 1982).

The search for a mechanism by which Azospirillum promotes plant growth is somewhat more complicated (Vande Broek and Vanderleyden, 1995). Azospirillum mutants have been induced by chemical radiation, $\mathrm{Tn}_{5}$ mutagenesis and gene replacement. Using $\mathrm{N}$ - methyl-N-Nitro-N nitroguanidine mutagenesis, NIF-mutants, defective in nitrogen fixation (Pedrosa and Yates, 1984). $\mathrm{Tn}_{5}$ nutagenesis has been used to obtain auxotrophic and IAA-over producing mutants of Azospirillum (Klingmuller, 1982).

During the last few years, several controlled -release $\mathrm{N}$ fertilizers were developed mainly to improve the efficiency of $\mathrm{N}$ used by plants, minimize the loss of nutrients via leaching and to reduce to the lower extent the great pollution occurred in our environment (Wang and Alva, 1996). They considered new approaches for amending the plants with their requirements from nutrients at the optimum rate.

Inoculation with Argininelss 1, methionineless, Threonineless, Alanineless, Adenineless, Prolineless, Thymineless, Lysineless, Agrginineless 2 and Histidineless 2, in ascending order was favourable for improving growth, yield and quality parameters of Banaty grapevines. Putting in our consideration the yield and fruit quality, fertilizing mature Banaty grapevines with $\mathrm{N}$ at $100 \mathrm{~g} / \mathrm{vine}$ through the Azotobacter vinelandii mutant Histidineless 2 at $100 \mathrm{ml} /$ vine plus $150 \mathrm{~g}$ ammonium nitrate/vine proved to be very effective for obtaining high and better fruit quality. (Uwakiem, 2006 and Ahmed et al., 2007).

Organic and biofertilzation when used as a partial replacement of inorganic $\mathrm{N}$ fertilizers were responsible for enhancing $N$ fixation, organic matter, water retention, availability of nutrients, root development, the biosynthesis of hormones and antibiotics and reducing soil pH (El-Sisy, 2000; Kannaiyan, 2002 and Cabrera et al., 2003).

Shaaban, (2014) pointed out that supplying Superior grapevines with mineral $\mathrm{N}, \mathrm{P}$ and $\mathrm{K}$ fertilizers at $50 \%$ plus $50 \%$ plant compost, rock phosphate, feldspar and biofertilzation namely Biogen, phosphorin and potassiumage was very effective in improving growth and fruiting over the application of mineral $\mathrm{N}$ alone. Previous studies showed that using organic and biofertilization as partial replacement of inorganic $\mathrm{N}$ fertilizers was very beneficial in improving growth, vine nutritional status, yield and berries quality (Dakhly et al., 2007; Uwakiem, 2011; Abou El-Lail, 2012; AllamAida et al., 2012; Shaheen et al., 2013; Ahmed et al., 2014; Abd El-Kareem, 2014; El-Wany, 2015; Abd El-Reheem, 2015; Aly- 
Samar, 2015; Tony, 2016; Ahmed et al., 2017 and El-Kady-Hanaa, 2017).

Slow release $\mathrm{N}$ fertilizers were responsible for improving yield and berries quality in different fruit crops (IbrahimAsmaa, 2001; Gobara et al., 2003 and Ahmed and Abada, 2012).

The target of this study was examining the effect of some newly microbial strains produced from Azospirillum brasilense and some slow release $\mathrm{N}$ fertilizers as partial replacement of mineral $\mathrm{N}$ fertilizers on fruiting of Superior grapevines.

\section{MATERIALS AND METHODS}

This study was carried out during the two consecutive seasons of 2015 and 2016 on sixty uniform in vigour 8-years old Superior grapevines grown in a private vineyard located at El-Hawarta Village, Minia district, Minia Governorate where the soil texture is clay (Table 1) and well drained water since water table depth is not less than two meters. The chosen vines are planted at $2 \mathrm{x}$ 3 meters apart. Cane pruning system was followed at the first week of January leaving 84 eyes per vine (on the basis of six fruiting canes $x 12$ eyes plus six renewal spurs $x$ two eyes) with the assistance of Gable shape supporting system. The vines were irrigated through surface irrigation system using Nile water.

Except those dealing with the present treatments (all sources of $\mathrm{N}$ and biofertilization), all the selected vines (60 vines) received the usual horticultural practices which are commonly used in the vineyard.

\section{1- Production of different $\mathrm{N}$ microbial strains:}

Lab. Experiment was carried out during the 2014 at the biofertilizer center of Fac. of Agric., Minia Univ.

\section{1-1 The used microorganisms:}

Azospirillum brasilense and their mutants were provided from the biofertilizers center of Fac. Agric. Minia Univ.

\section{2- Inocula preparation:}

For preparation of Azospirillum brasilense and their mutants inocula in malate medium (in grams per litter: $\mathrm{KH}_{2} \mathrm{Po}_{4}$ $0.4 ; \mathrm{K}_{2} \mathrm{HPO}_{4} 0.1 ; \mathrm{Mg} \mathrm{So}_{4} .7 \mathrm{H}_{2} \mathrm{O} 0.2 ; \mathrm{NaCl}$ $0.1 ; \mathrm{CaCl} 0.02 ; \mathrm{FeCl}_{3} 0.01 ; \mathrm{Na}_{2} \mathrm{MO}_{4} .2 \mathrm{H}_{2} \mathrm{O}$ 0.002 ; sodium malate 5.0 ; yeast extract 0.05 and $\mathrm{pH}$ 7. 2- 7.4) was used.

Minimal medium (MM) of Mckenney and Melton, (1986) was used to isolate the auxotrophic mutants of Azospirillum, composed of Mannitol $10.0 \mathrm{gm}, \mathrm{K}_{2} \mathrm{HPO}_{4}$ $0.5 \mathrm{gm}, \mathrm{Mg} \mathrm{50} \mathrm{O}_{4} 7 \mathrm{H}_{2} \mathrm{O} 0.20 \mathrm{gm}, \mathrm{NaCl} 0.20$ gm, Mn SO $0_{4} .4 \mathrm{H}_{2} \mathrm{O}$ trace, $\mathrm{FeCl}_{3}$ trace, $\mathrm{N}_{2}$ molybdate trace, $\mathrm{CaCO}_{3} 5.0 \mathrm{gm}$, Agar 20.0 $\mathrm{gm}$ and distilled water up $1000 \mathrm{ml}$.

\section{3- Inoculation process:}

Each vine inoculated with 5,10 and $20 \mathrm{ml}$ from cell suspension diluted in 2 liter water and then the vines were irrigated.

This study included the following ten treatments:

1. Using $\mathrm{N}$ as $100 \%$ Mineral Nitrogen (MN) (179.1g ammonium nitrate).

2. Using $\mathrm{N}$ as $75 \% \mathrm{MN}$ (134.4 g ammonium nitrate) $+25 \%$ slow 1 Ureaformaldehyde $\left(\begin{array}{llll}41 \% & N\end{array}\right) \quad(36.6 \quad \mathrm{~g})+$ strain $_{1}$ (Methionineless) at $5 \mathrm{ml} / \mathrm{vine}$

3. Using $\mathrm{N}$ as $50 \% \mathrm{MN}$ (89.6 g ammonium nitrate) $+50 \%$ slow $_{1}$ Ureaformaldehyde $(41 \% \quad \mathrm{~N}) \quad(73.2 \mathrm{~g})+$ strain $_{1}$ (Methionineless) at $10 \mathrm{ml} / \mathrm{vine}$

4. Using $\mathrm{N}$ as $25 \% \mathrm{MN}$ (44.8 g ammonium nitrate) $+75 \%$ slow $_{1}$ Ureaformaldehyde $\left(\begin{array}{ll}41 \% & \mathrm{~N}\end{array}\right) \quad(109.8 \mathrm{~g})+$ strain $_{1}$ (Methionineless) at $20 \mathrm{ml} / \mathrm{vine}$

5. Using $\mathrm{N}$ as $75 \% \mathrm{MN}$ (134.4 $\mathrm{g}$ ammonium nitrate) $+25 \%$ slow $_{2}$ (Sulphur - coated urea $(41 \% \mathrm{~N}) \quad(36.6 \mathrm{~g})+$ strain $_{2}$ (Threonineless) at $5 \mathrm{ml} / \mathrm{vine}$

6. Using $\mathrm{N}$ as $50 \% \mathrm{MN}$ (89.6 g ammonium nitrate) $+50 \%$ slow $_{2}$ (Sulphur - coated urea $(41 \% \mathrm{~N}) \quad(73.2 \mathrm{~g})+$ strain $_{2}$ (Threonineless) at $10 \mathrm{ml} / \mathrm{vine}$

7. Using $\mathrm{N}$ as $25 \% \mathrm{MN}$ (44.8 g ammonium nitrate) $+75 \%$ slow $_{2}$ (Sulphur - coated urea $\left(41 \%\right.$ N) $\left(109.8\right.$ g) + strain $_{2}$ (Threonineless) at $20 \mathrm{ml} / \mathrm{vine}$ 


\section{F. F. Ahmed, et al.,}

8. Using $\mathrm{N}$ as $75 \% \mathrm{MN}(134.4 \mathrm{~g}$ ammonium nitrate) $+25 \%$ slow $_{3}$ (Methylene urea $(22 \% \mathrm{~N})(68.2 \mathrm{~g})+\operatorname{strain}_{3}$ (Tyrosineless) at $5 \mathrm{ml} / \mathrm{vine}$

9. Using $\mathrm{N}$ as $50 \% \mathrm{MN}(89.6 \mathrm{~g}$ ammonium nitrate) $+50 \%$ slow $_{3}$ (Methylene urea $(22 \% \mathrm{~N})(136.4 \mathrm{~g})+\operatorname{strain}_{3}$ (Tyrosineless) at $10 \mathrm{ml} / \mathrm{vine}$

10.Using $\mathrm{N}$ as $25 \% \mathrm{MN}(44.8 \mathrm{~g}$ ammonium nitrate) $+75 \%$ slow $_{3}$ (Methylene urea $(22 \% \mathrm{~N})(204.6 \mathrm{~g})+$ strain $_{3}$ (Tyrosineless) at $20 \mathrm{ml} / \mathrm{vine}$

Each treatment was replicated three times, two vines per each. Ammonium nitrate $(33.5 \% \mathrm{~N})$ as a source of inorganic $\mathrm{N}$ was divided into three unequal batches as $40 \%$ at growth start (1st week of March), $40 \%$ just after berry setting (3rd week of April) and $20 \% 30$ day after harvesting. All bacterial strains were added once in shallow holes $20 \mathrm{~cm}$ apart from the trunk and covered with moist soil. The three slow release fertilizers Slow $_{1}=$ Ureaformaldehyde $(41 \% \mathrm{~N})$, Slow $_{2}=$ Sulphur - coated urea $(41 \% \mathrm{~N})$ and $\mathrm{Slow}_{3}=$ Methylene urea $(22 \%$ $\mathrm{N})$ were added once before growth start (1st week of March) $50 \mathrm{~cm}$ far from the vine trunk in drenches $(50 \times 50 \times 50 \mathrm{~cm}$ dimensions $)$. The organic fertilizers namely plant compost $(2 \%$ N) was added at fixed rate namely $0.25 \mathrm{~kg} /$ vine. It was added once just after winter pruning ( $3^{\text {rd }}$ of January) in shallow holes 20 $\mathrm{cm}$ a part from the trunk and covered with soil. Analyses of plant compost are given in Table (2).

Randomized complete block design (RCBD) was followed (Rangaswamy, 1995), where the experiment consisted of ten treatments, each treatment was replicated three times, two vines per each.

During both seasons, the following measurements were recorded:

1. Growth aspects namely main shoot length $(\mathrm{cm})$, leaf area $(\mathrm{cm})^{2}$ (Ahmed and Morsy, 1999), pruning wood weight/vine, wood ripening coefficient (Bouard, 1966) and cane thickness $(\mathrm{cm})$..

2. Leaf chemical components namely chlorophylls a, b, total chlorophylls (mg/1g F.W) (Von- Wettstein, 1975), N, P and $\mathrm{K}$ (Wilde et al. 1985 and Balo et al, 1988).

3. Percentage of berry setting.

4. Percentage of total carbohydrates in canes (Smith et al.,1956).

Table (1): Analysis of the tested soil:

\begin{tabular}{|l|c|}
\hline \multicolumn{1}{|c|}{ Constituents } & Values \\
\hline \hline Particle size distribution: & \\
\hline Sand \% & 7.0 \\
\hline Silt \% & 21.5 \\
\hline Clay \% & 71.5 \\
\hline Texture & Clay \\
\hline $\mathrm{pH}(1: 2.5$ extract) & 7.95 \\
\hline $\mathrm{EC}(1: 2.5$ extract $)\left(\mathrm{dsm}^{-1}\right) 1 \mathrm{~cm} / 25^{\circ} \mathrm{C}$. & 0.97 \\
\hline O.M. \% & 2.01 \\
\hline CaCO $\%$ & 2.41 \\
\hline Total $\mathrm{N} \%$ & 0.11 \\
\hline Available P ( Olsen, $\mathrm{ppm})$ & 3.11 \\
\hline Available K (ammonium acetate, $\mathrm{ppm})$ & 405.9 \\
\hline
\end{tabular}


Effect of some azospirillum strains as a partial replacement of ....................

Table (2): Analysis of plant compost.

\begin{tabular}{|l|c|}
\hline \multicolumn{1}{|c|}{ Parameters } & Values \\
\hline \hline Cubic meter weight $(\mathrm{kg})$. & 600.0 \\
\hline Moisture \% & 29.0 \\
\hline Organic matter \% & 30.7 \\
\hline Organic carbon \% & 28.56 \\
\hline $\mathrm{pH}(1: 2.5$ extract) & 27.25 \\
\hline $\mathrm{EC}\left(\right.$ dsm $\left.{ }^{-1}\right)(1: 2.5$ extract) & 10.25 \\
\hline C/N ratio & 14.28 \\
\hline Total $\mathrm{N} \%$ & 2.0 \\
\hline Total $\mathrm{P} \%$ & 1.02 \\
\hline Total $\mathrm{K} \%$ & 1.21 \\
\hline Total $\mathrm{Ca} \%$ & 1.25 \\
\hline Total $\mathrm{Mg} \%$ & 1.30 \\
\hline Total $\mathrm{Fe}(\mathrm{ppm})$ & 18.5 \\
\hline Total $\mathrm{Mn}(\mathrm{ppm})$ & 37.55 \\
\hline Total $\mathrm{Zn}(\mathrm{ppm})$ & 43.22 \\
\hline Total $\mathrm{Cu}(\mathrm{ppm})$ & 17.40 \\
\hline
\end{tabular}

5. Yield expressed in weight (kg.) and number of clusters/vine as well as cluster weight and dimensions (length and shoulder).

6. Percentages of shot berries.

7. Physical and chemical characteristics of the berries namely weight, longitudinal and equatorial, T.S.S. $\%$, total acidity $\%$, reducing sugars\% (Lane and Eynon, 1965 and A.O.A.C, 2000) and nitrite in the juice (ppm) (Ridnour-Lisa et al., 2000), total count of bacteria in the soil was counted (cfug)/1.0g soil (Cochran,1950).

Statistical analysis was done and treatment means were compared using new L.S.D. at 5\% (according to Rao, 2007).

\section{RESULTS AND DISCUSSION} 1-Number and percentages of Azospirillum brasilense survivals after treatment with different concentrations of Acriflavine mutagen:

It is clear from the obtained data in Tables (3 and 4) and Fig. (1) that exposing
Azospirillum wild type to Acriflavine for three concentrations was accompanied with decreasing numbers and percentages of Azospirillum brasilense survivals compared to control (non treatment).

Treating Azospirillum brasilense with Acriflavine produced 2500 number and 100 percentage of survival. However, numbers of survivals were $500,150,50$ after treatment with Acriflavine for $0.01,0.05$ and 0.10 $\mathrm{mg} / \mathrm{ml}$ cell suspension however,percentage of survivals recorded 20.0, 6.0 and 2.0 percentage of survivals, respectively. Many nif mutants have been characterized biochemically (Roberts and Brill, 1981). Santero et al., (1986) reported the isolation of mutants, selected on the basis of their chlorate resistance that are affected in a general control of nitrogen metabolism.

Fong and Bockrath, (1979) suggested that, at a concentration insufficient to alter survival of unirradiated cells of E.coli, Acriflavine (2 $\mathrm{Mg} / \mathrm{ml})$ inhibited both simglestrand deoxyribonucleic acid breakage and post replication repair after ultraviolet irritation. 
Table (3): Number and percentages of Azospirillum brasilense survivals after treatment with different concentrations of Acriflavine for 1 and 2 hours.

\begin{tabular}{|c|c|c|c|c|}
\hline \multirow[t]{2}{*}{ Organism } & \multirow[t]{2}{*}{ AC. conc. } & \multirow[t]{2}{*}{ Time (hrs) } & \multicolumn{2}{|c|}{ No. and percentage of survivals } \\
\hline & & & No & $\%$ \\
\hline \multirow{8}{*}{ Azospirillum brasilense } & Control & \multirow{4}{*}{$1(\mathrm{hr})$} & 12500 & 100 \\
\hline & 0.01 & & 9725 & 77.80 \\
\hline & 0.05 & & 6250 & 50.00 \\
\hline & 0.10 & & 2200 & 17.60 \\
\hline & Control & \multirow{4}{*}{2 (hrs) } & 12500 & 100 \\
\hline & 0.01 & & 5125 & 41.00 \\
\hline & 0.05 & & 1975 & 15.80 \\
\hline & 0.10 & & 0.000 & 00.00 \\
\hline
\end{tabular}

Table (4): Percentages and Numbers of characterization single mutants resulted by concentrations of Acriflavine in Azospirillum brasilense

\begin{tabular}{|c|c|c|c|c|c|c|c|c|c|c|}
\hline \multirow{2}{*}{ Time } & \multirow{2}{*}{$\begin{array}{l}\text { AC. } \\
\text { Conc }\end{array}$} & \multirow{2}{*}{$\begin{array}{l}\text { No.of } \\
\text { colonies } \\
\text { tested }\end{array}$} & \multirow{2}{*}{$\begin{array}{l}\text { No.of } \\
\text { mutants }\end{array}$} & \multirow{2}{*}{$\begin{array}{l}\text { Mutants } \\
\text { freq. } \%\end{array}$} & \multicolumn{6}{|c|}{ No. and percentage of characterization } \\
\hline & & & & & Meth ${ }^{-}$ & $\mathrm{His}^{-}$ & $\mathrm{Arg}^{-}$ & Thr & Tyro ${ }^{-}$ & Ala \\
\hline \multirow[t]{3}{*}{1 (hr) } & 0.01 & 278 & 8 & 2.87 & 1 & 1 & 3 & 0 & 1 & 2 \\
\hline & 0.05 & 350 & 10 & 2.85 & 2 & 2 & 1 & 1 & 2 & 2 \\
\hline & 0.10 & 379 & 15 & 3.95 & 2 & 3 & 3 & 4 & 1 & 2 \\
\hline \multirow[t]{3}{*}{2 (hrs) } & 0.01 & 300 & 30 & 10 & 10 & 2 & 7 & 8 & 2 & 1 \\
\hline & 0.05 & 250 & 28 & 11.2 & 3 & 5 & 6 & 3 & 3 & 8 \\
\hline & 0.10 & 0 & 0 & 0.0 & 0 & 0 & 0 & 0 & 0 & 0 \\
\hline
\end{tabular}

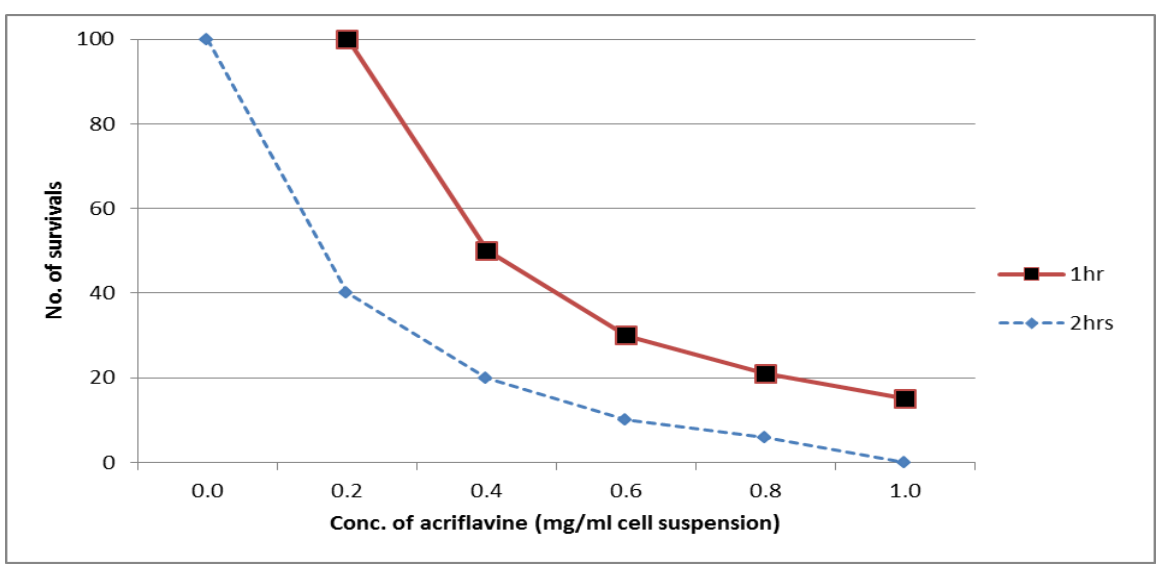

Figure (1): Azosperillum brasilense survived different acriflavine concentrations and incubations for 1 and 2 hours at $30^{\circ} \mathrm{c}$. 


\section{2- Some vegetative growth characteristics:}

Data in Table (5) clearly show that the six growth aspects namely main shoot length, number of leaves/ shoot, leaf area, wood ripening coefficient, pruning wood weight and cane thickness were significantly affected by varying $\mathrm{N}$ management. Using mineral $\mathrm{N}$ (ammonium nitrate) at 50 to $75 \%$, the three slow release $\mathrm{N}$ fertilizers (Methylene urea, sulphur coated urea and urea formaldehyde) at 25 to $50 \%$ + bacteria strains ( Methionineless, Threonineless and Tyrosineless) each at 5 to $20 \mathrm{ml} /$ vine significantly were followed by enhancing the six growth characteristics namely main shoot length, number of leaves/ shoot, leaf area, wood ripening coefficient, pruning wood weight and cane thickness over the application of $\mathrm{N}$ as $100 \%$ inorganic $\mathrm{N}$ alone or when mineral $\mathrm{N}$ was applied at $25 \%$ of the suitable $\mathrm{N}$ even with the application of slow release $\mathrm{N}$ fertilizers and the three namely $\mathrm{N}$ strains. Increasing percentages of inorganic $\mathrm{N}$ from 50 to $75 \%$ and at the same time increasing percentages of the three slow release fertilizers from 25 to $50 \%$ and bacterial strains from 5 to $10 \mathrm{ml} /$ vines significantly was followed by stimulating the previously mentioned six growth aspects. The best percentage of ammonium nitrate was $50 \%$. The beneficial effects of these slow release $\mathrm{N}$ fertilizers on enhancing growth aspects can be arranged as follows in ascending order ureaformaldehyde, sulphur coated and methylene urea.

The best bacterial strains was Tyrosineless followed by Threonineless and Methionineless. The maximum values of shoot length $(116.7 \& 117.5 \mathrm{~cm})$, number of leaves/shoot ( $27.0 \& 27.8)$, leaf area (112.0 \& $\left.112.6 \mathrm{~cm}^{2}\right)$, wood ripening coefficient (0.81 \& 0.83), pruning wood weight (2.41 \& $2.50 \mathrm{~kg})$ and cane thickness (1.40 \& 1.42 $\mathrm{cm})$ were recorded on the vines that received $\mathrm{N}$ as $50 \%$ mineral $\mathrm{N}+50 \%$ methylene urea and Tryosineless $\mathrm{N}$ strains at $10 \mathrm{ml} / \mathrm{vine}$. The lowest values of these growth traits were recorded on the vines that received $\mathrm{N}$ as $25 \%$ mineral $\mathrm{N}+75 \%$ the slow release $\mathrm{N}$ fertilizer namely ureaformaldehyde and the $\mathrm{N}$ strain namely methionineless at $20 \mathrm{ml} / \mathrm{vine}$. These results were true during the two seasons.

\section{3- Leaf and cane chemical components:}

It is clear from the obtained data in Tables (6 \& 7) that the supplying the vines with $\mathrm{N}$ as 50 to $75 \%$ inorganic $\mathrm{N}+$ any one of the three slow release $\mathrm{N}$ fertilizer (Methylene urea, Sulphur coated urea and urea formaldehyde) + bacteria strains (Methionineless, Threonineless and Tyrosineless) each at 5 to $10 \mathrm{ml} /$ vine significantly was followed by enhancing the seven chemicals namely cane total carbohydrates \% as well as percentages of $\mathrm{N}, \mathrm{P}, \mathrm{K}, \mathrm{Mg}, \mathrm{Ca}$ and $\mathrm{S}$ in the leaves relative to using $\mathrm{N}$ via $100 \% \mathrm{MN}$ or when $\mathrm{N}$ was added as $25 \% \mathrm{MN}$.

There was a gradual promotion on these nutrients and total carbohydrates with reducing the percentages of inorganic $\mathrm{N}$ from 100 to $50 \%$ and at the same time increasing the percentages of the three slow release $\mathrm{N}$ fertilizers from 25 to $50 \%$ and bacterial strains from 5 to $10 \mathrm{ml} /$ vine.

The best slow release fertilizer and $\mathrm{N}$ bacterial strains applied with mineral $\mathrm{N}$ was methylene urea and $\mathrm{N}$ strain namely Tyrosineless, respectively.

The maximum values of cane total carbohydrates (17.3 \& $17.1 \%), \mathrm{N}(2.11$ \& 2.13), $P(0.161 \& 0.156 \%), K(1.84 \& 1.75$ $\%), \mathrm{Mg}(0.89 \& 0.93), \mathrm{Ca}(2.61 \& 2.70 \%)$ and S (0.99 \& $0.98 \%)$ were recorded on the vines that received $\mathrm{N}$ as $50 \% \mathrm{MN}+50 \%$ methylene urea and Tyrosineless bacterial at $10 \mathrm{ml} / \mathrm{vine}$ during both seasons, respectively. The vines fertilized with $\mathrm{N}$ as $25 \% \mathrm{MN}+75 \%$ the slow release $\mathrm{N}$ fertilizers urea formaldyhde + bacterial strain namely methioneless at $20 \mathrm{ml} / \mathrm{vine}$ gave the lowest values. These results were true during both seasons. 


\section{F. F. Ahmed, et al.,}

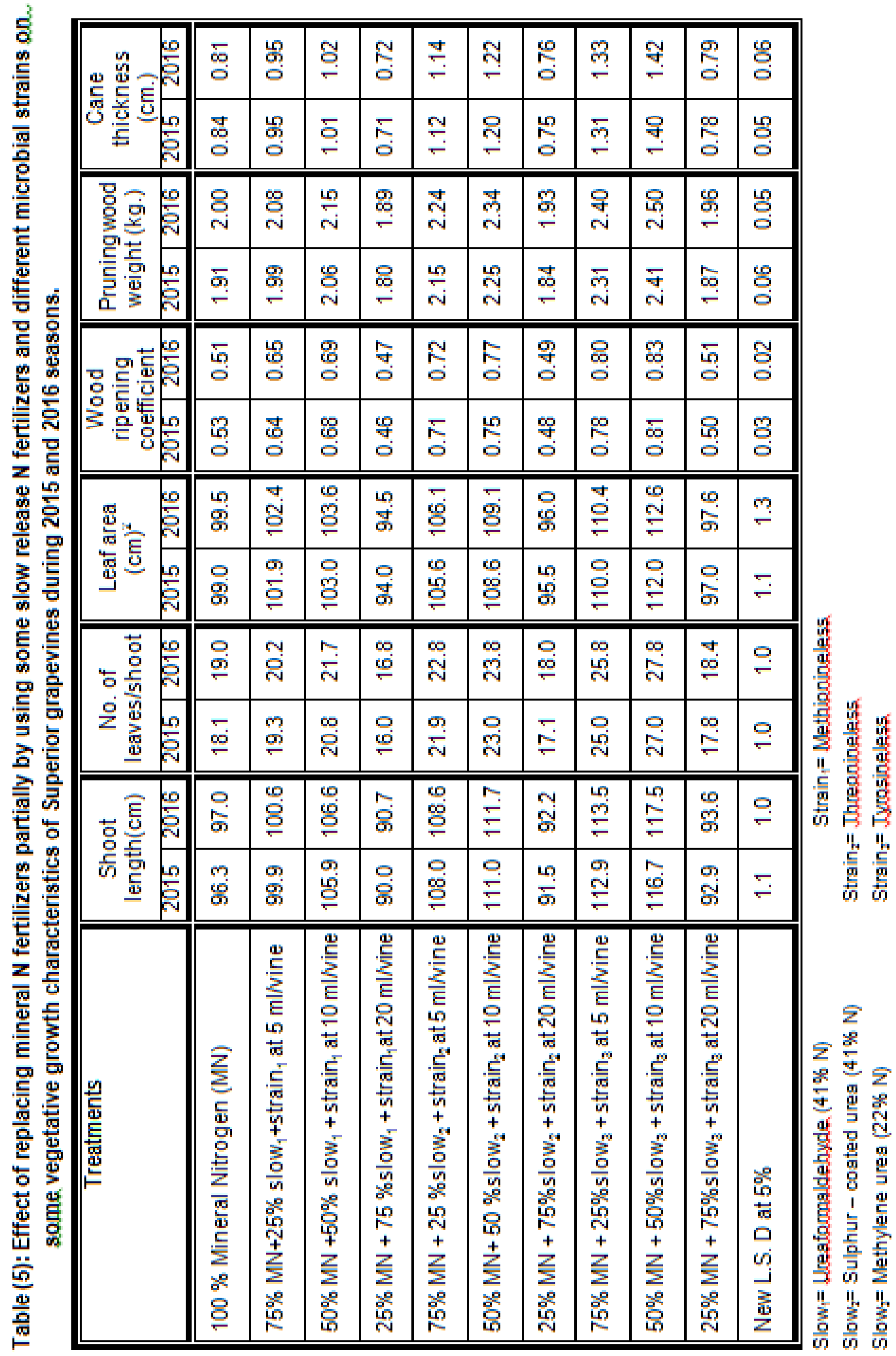




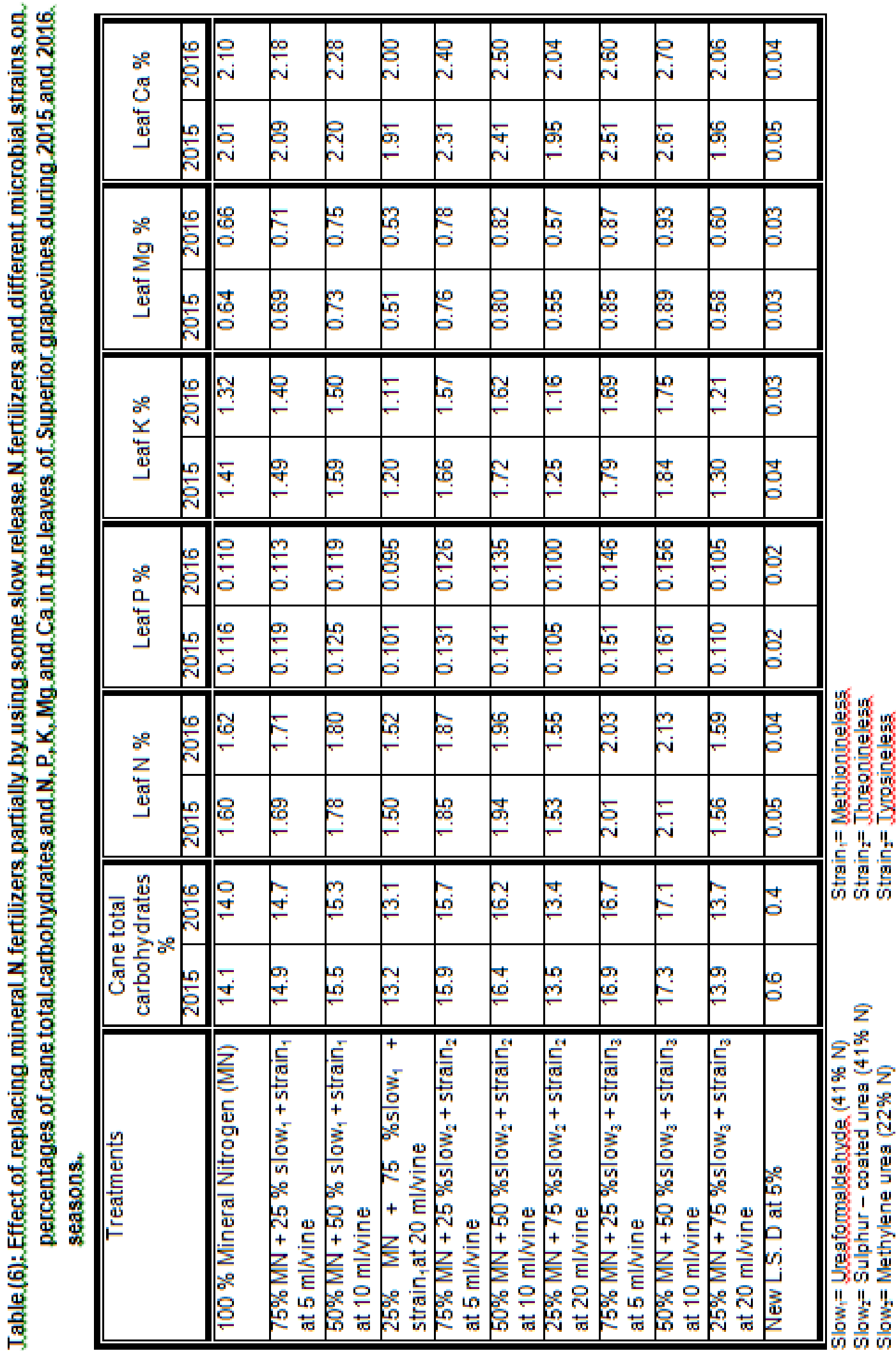




\section{F. F. Ahmed, et al.,}

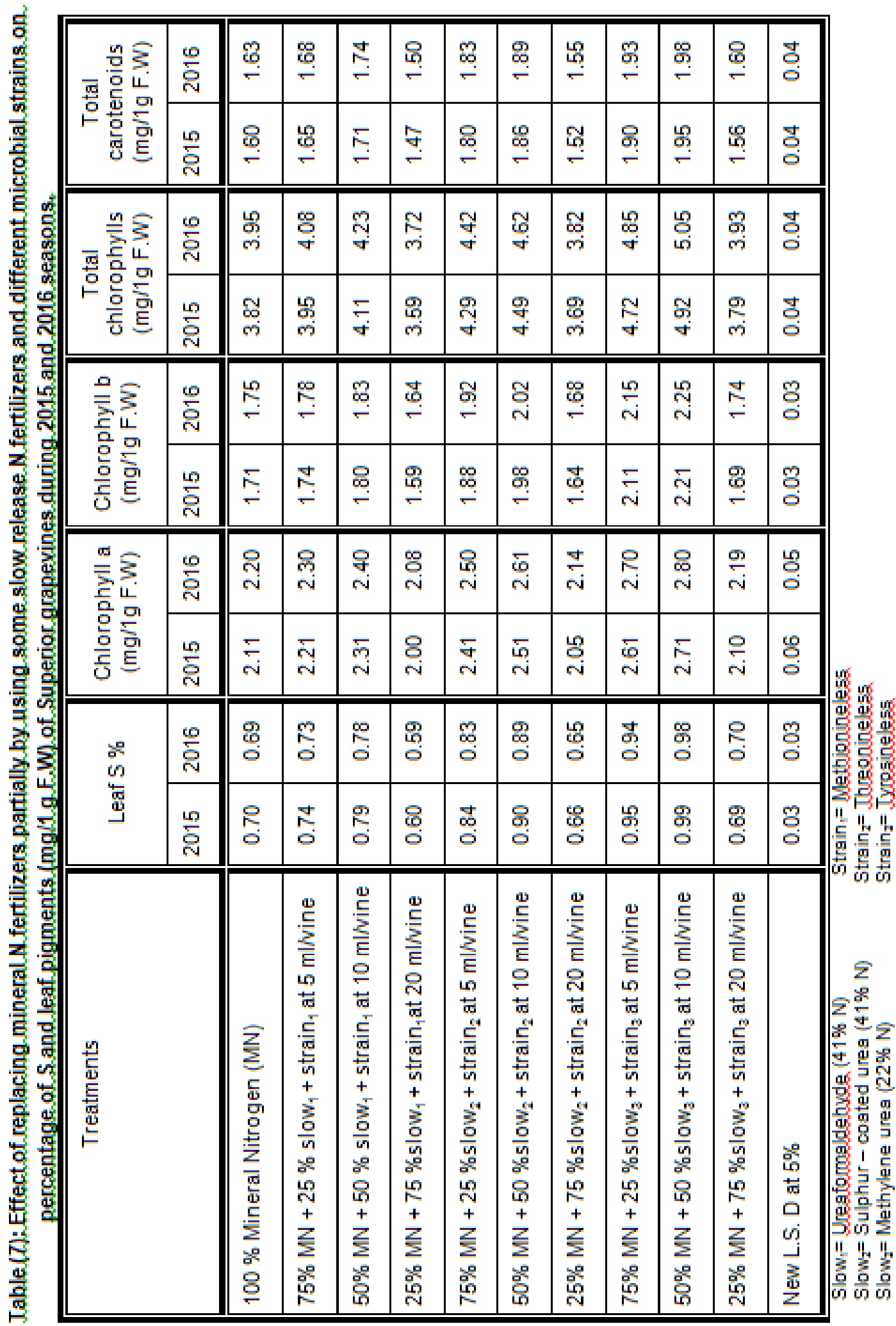




\section{4- Leaf pigments:}

As shown in Table (7) plant pigments namely chlorophyll a \& b, total chlorophylls and total carotenoids were significantly varied among the ten $\mathrm{N}$ management treatments. These pigments were significantly enhanced in response to supplying the vines with $\mathrm{N}$ via 50 to $75 \%$ $\mathrm{MN}$ + any one of the slow release $\mathrm{N}$ fertilizer Methylene urea, Sulphur coated urea and urea formaldehyde) + bacteria strains (Methionineless, Threonineless and Tyrosineless) each at 5 to $10 \mathrm{ml} / \mathrm{vine}$ relative to the application of $\mathrm{N}$ as $100 \%$ inorganic $\mathrm{N}$ or when inorganic $\mathrm{N}$ was applied at $25 \%$ even with the application of slow release $\mathrm{N}$ fertilizer each at $75 \%$ and bacterial strains at $20 \mathrm{ml} / \mathrm{vine}$. The three bacterial strains could be arranged as follows regarding their positive action on leaf pigments Methionineless, Threonineless and Tyrosineless in ascending order. The best results were observed due to using urea formaldehyde, sulphur coated urtea and methylene urea, in ascending order. The promotion was associated with reducing mineral $\mathrm{N}$ percentage from 100 to $50 \%$ and increasing percentages of slow release $\mathrm{N}$ fertilizers from 25 to $75 \%$ and $\mathrm{N}$ bacterial from 5 to $10 \mathrm{ml} / \mathrm{vine}$. Supplying Superior grapevines with $\mathrm{N}$ via $50 \%$ mineral $\mathrm{N}+$ methylone urea at $50 \%+\mathrm{N}$ bacterial strain namely Tyrosineless at $10 \mathrm{ml} /$ vine gave the maximum values. The lowest values were recorded on the vines that supplied with $\mathrm{N}$ as $25 \% \mathrm{MN}+75 \%$ the slow release $\mathrm{N}$ fertilizers urea formaldyhde + bacterial strain namely methioneless at $20 \mathrm{ml} / \mathrm{vine}$. Similar results were announced during the two seasons.

\section{5- Berry setting \%, yield and cluster aspects:}

It is worth to mention from the data in Table (8) that berry setting \%, yield expressed in weight and number of clusters /vine, weight, length and shoulder of cluster were significantly varied among the ten $\mathrm{N}$ management.
Amending the vines with $\mathrm{MN}$ at 50 to $75 \%+25$ to $50 \%$ any slow release $\mathrm{N}$ fertilizer (Methylene urea, Sulphur coated urea and urea formaldehyde) + bacteria strains (Methionineless, Threonineless and Tyrosineless) each at 5 to $10 \mathrm{ml} / \mathrm{vine}$ had significant promotion on berry setting \%, yield and cluster aspects relative to the application of $\mathrm{N}$ via $\mathrm{MN}$ alone or when $\mathrm{MN}$ was added via $25 \%$ even with the application of slow release $\mathrm{N}$ fertilizers and bacterial strains. The promotion was significantly associated with reducing inorganic $\mathrm{N}$ from 100 to $50 \%$ and at the same time increasing percentages of the slow release $\mathrm{N}$ fertilizers from 25 to $50 \%$ and levels of bacterial strain from 5 to 10 $\mathrm{ml} / \mathrm{vine}$. A significant reduction on these parameters was detected with reducing the percentages of inorganic $\mathrm{N}$ from 50 to $25 \%$ regardless the application of slow release $\mathrm{N}$ fertilizer and bacterial strains. Using $\mathrm{N}$ as $100 \%$ inorganic $N$ was significantly preferable than using $\mathrm{N}$ as $25 \%$ inorganic $\mathrm{N}$ $+75 \%$ any slow release $\mathrm{N}$ fertilizers (Methylene urea, Sulphur coated urea and urea formaldehyde) + bacteria strains (Methionineless, Threonineless and Tyrosineless) at $20 \mathrm{ml} / \mathrm{vine}$. The maximum yield $/$ vine $(8.87 \& 11.9 \mathrm{~kg} / \mathrm{vine})$ during both seasons, respectively were recorded on the vines that received $\mathrm{N}$ as $50 \% \mathrm{MN}+50 \%$ methylene urea $+10 \mathrm{ml}$ tyrosineless bacterial strain. The vines treated with $\mathrm{N}$ completely via inorganic $\mathrm{N}$ form gave 7.5 \& $9.0 \mathrm{~kg}$ during both seasons, respectively. The percentage of increment on the yield above the check treatment (using $\mathrm{N}$ as $100 \% \mathrm{~N}$ reached $13.5 \& 31.5 \%$ ) during both seasons, respectively. Number of clusters /vine in the first season was unaffected by the present treatments in the first season of study. The previous beneficial effect of slow release $\mathrm{N}$ fertilizers as well as organic and biofertilizers on growth and vine nutritional status surely reflected on improving berry setting and cluster weight consequently the yield. 


\section{F. F. Ahmed, et al.,}

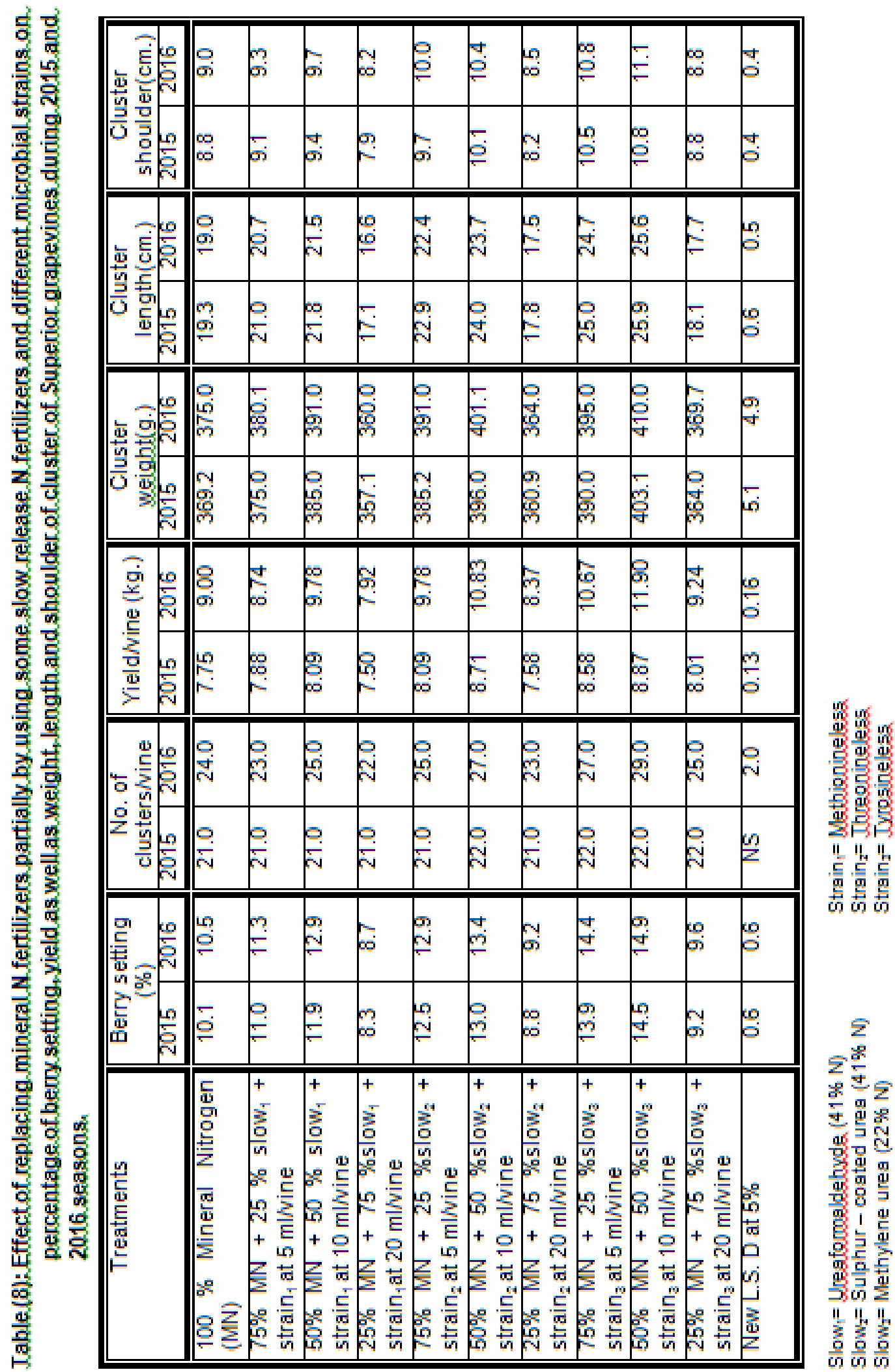




\section{6- Percentage of shot berries:}

Table (9) shows that shot berries \% was significantly regulated with supplying the vines with $\mathrm{MN}$ as 25 to $75 \%$ inorganic $\mathrm{N}+$ 25 to $75 \%$ any one of the three slow release $\mathrm{N}$ fertilizers or bacterial strains relative to application of $\mathrm{N}$ as $100 \% \mathrm{MN}$. The reduction was significantly in proportional to the reduction on the percentage of $\mathrm{MN}$ and at the same time the increase in concentration of slow release $\mathrm{N}$ fertilizer and the three bacterial strain and the best slow release fertilizers in controlling shot berries \% were ureaformaldehyde, sulphur coated urea and methylene urea, in ascending order. The lowest values (5.5 \& $5.2 \%$ ) were recorded on the vines that received $\mathrm{N}$ as $50 \% \mathrm{MN}+$ $50 \%$ methylene urea $+10 \mathrm{ml}$ Tyrosineless bacterial strain. The highest values (10.6 \& $11.0 \%$ ) were recorded on the vines received $\mathrm{N}$ as $100 \%$ inorganic $\mathrm{N}$. These results were true during both seasons. The reducing effect of the slow release $\mathrm{N}$ fertilizers and bioforms of $\mathrm{N}$ on shot berries might be attributed to their important roles in obtaining a good balance between various nutrients in plant tissues and enhancing nutritional status of the vines.

\section{7- Physical and chemical characteristics of the berries:}

It can be stated from the data in Tables

(9 \& 10) that treating the vines with $\mathrm{N}$ as 25 to $75 \% \mathrm{MN}+25$ to $75 \%$ slow release $\mathrm{N}$ fertilizers (Methylene urea, Sulphur coated urea and urea formaldehyde) + bacteria strains ( Methionineless, Threonineless and Tyrosineless) each at 5 to $20 \mathrm{ml} / \mathrm{vine}$ significantly was favourable in enhancing quality of the berries in terms of increasing berry weight and dimensions (longitudinal and equatorial), T.S.S.\% and reducing sugars and decreasing total acidity $\%$ and both nitrate and nitrite in the juice relative to the application of $\mathrm{N}$ as $100 \%$ inorganic $\mathrm{N}$. There was a gradual promotion on quality of the berries with reducing percentages of inorganic $\mathrm{N}$ and the same time increasing the percentages of slow release $\mathrm{N}$ fertilizers and the levels of $\mathrm{N}$ bacterial strains. The important roles of the three slow release $\mathrm{N}$ fertilizers on improving quality of the berries could be arranged as follows in descending order ureaformaldehyde, sulphur coated urea and methylene urea. The best results with regard to fruit quality were observed due to treating the vines with bacterial strains namely Methionineless, Threonineless and Tyrosineless, in descending order. The best results were obtained due to treating the vines with $25 \%$ $\mathrm{MN}+75 \%$ the slow release $\mathrm{N}$ fertilizer ureaformaldehyde at $75 \%$ and bacterial strains namely Methionineless at $20 \mathrm{ml} / \mathrm{vine}$. Unfavourable effects on quality of the berries were attributed to using $\mathrm{N}$ as $100 \%$ inorganic. The lowest values of nitrate $(1.50$ \& $1.41 \mathrm{ppm})$ and nitrite $(0.50 \& 0.47 \mathrm{ppm})$ were recorded on the vines that received $\mathrm{N}$ as $25 \%$ inorganic $\mathrm{N}+75 \%$ ureaformaldehyde + Methionineless bacterial strain at $20 \mathrm{ml} / \mathrm{vine}$. Similar trend was noticed during both seasons. The benefits of slow release $\mathrm{N}$ fertilizers and bioforms of $\mathrm{N}$ on adjusting $\mathrm{N}$ uptake as well as enhancing the uptake of $\mathrm{Mg}$ surely reflected on enhancing the biosynthesis of sugars and leaf pigments and advancing maturity stage and berries quality.

\section{8- Total counts of bacterial in the soil:}

Table (10) shows that all treatments involved the application of inorganic, slow release $\mathrm{N}$ fertilizers and bacterial strains significantly enhanced total counts of bacterial in the soil relative to using $\mathrm{N}$ as 100 $\%$ inorganic $\mathrm{N}$. The promotion on total counts of bacterial in the soil was significantly related to increasing percentage of slow release $\mathrm{N}$ fertilizer as well as levels of bacterial strains from 5 to $20 \mathrm{ml} /$ vine. The best slow release fertilizer in this respect were urea formaldehyde, sulphur coated urea and methylene urea, in ascending order. Using bacterial strains namely Methionineless, Threonineless and Tyrosineless, in ascending order was very 
F. F. Ahmed, et al.,

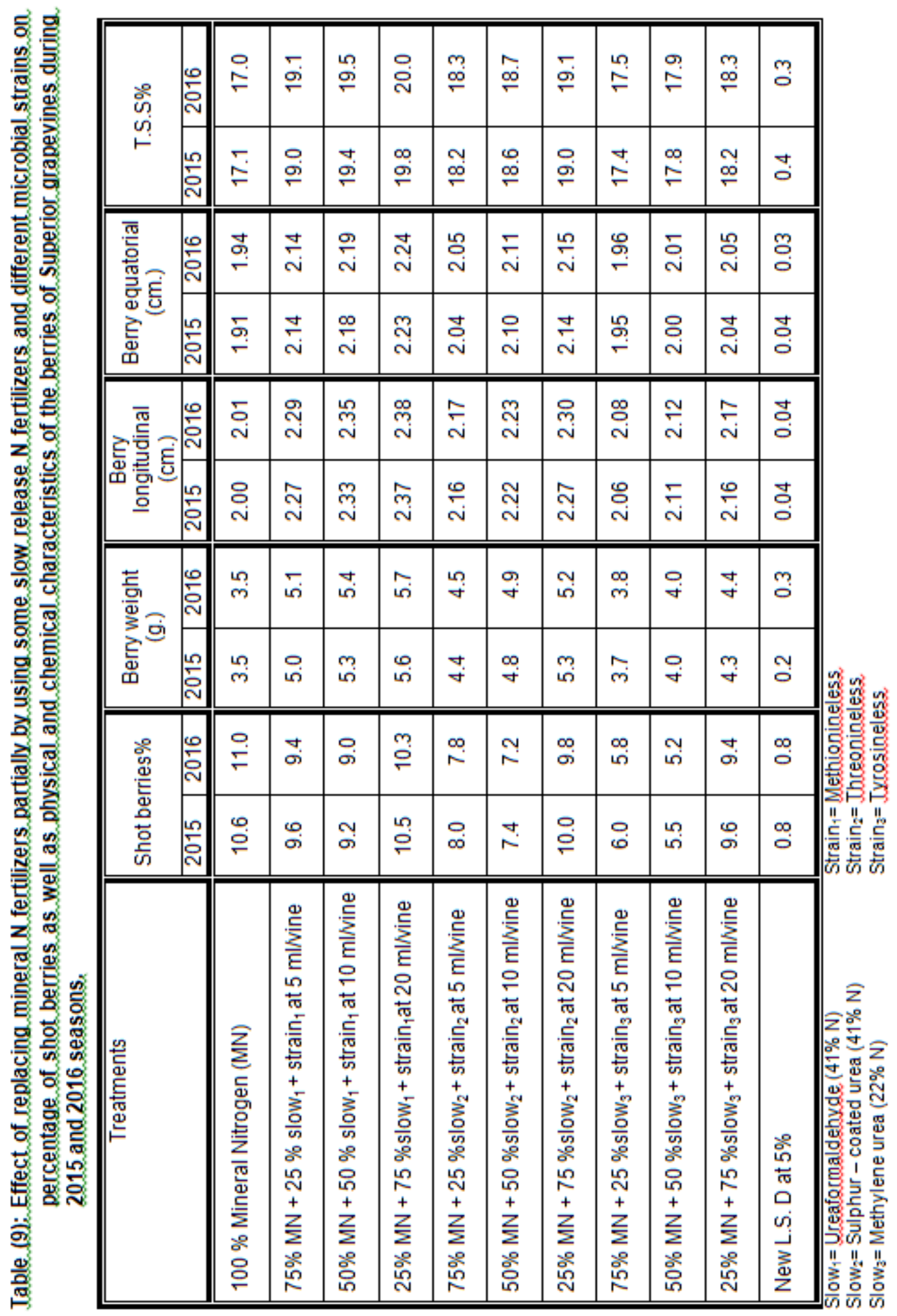




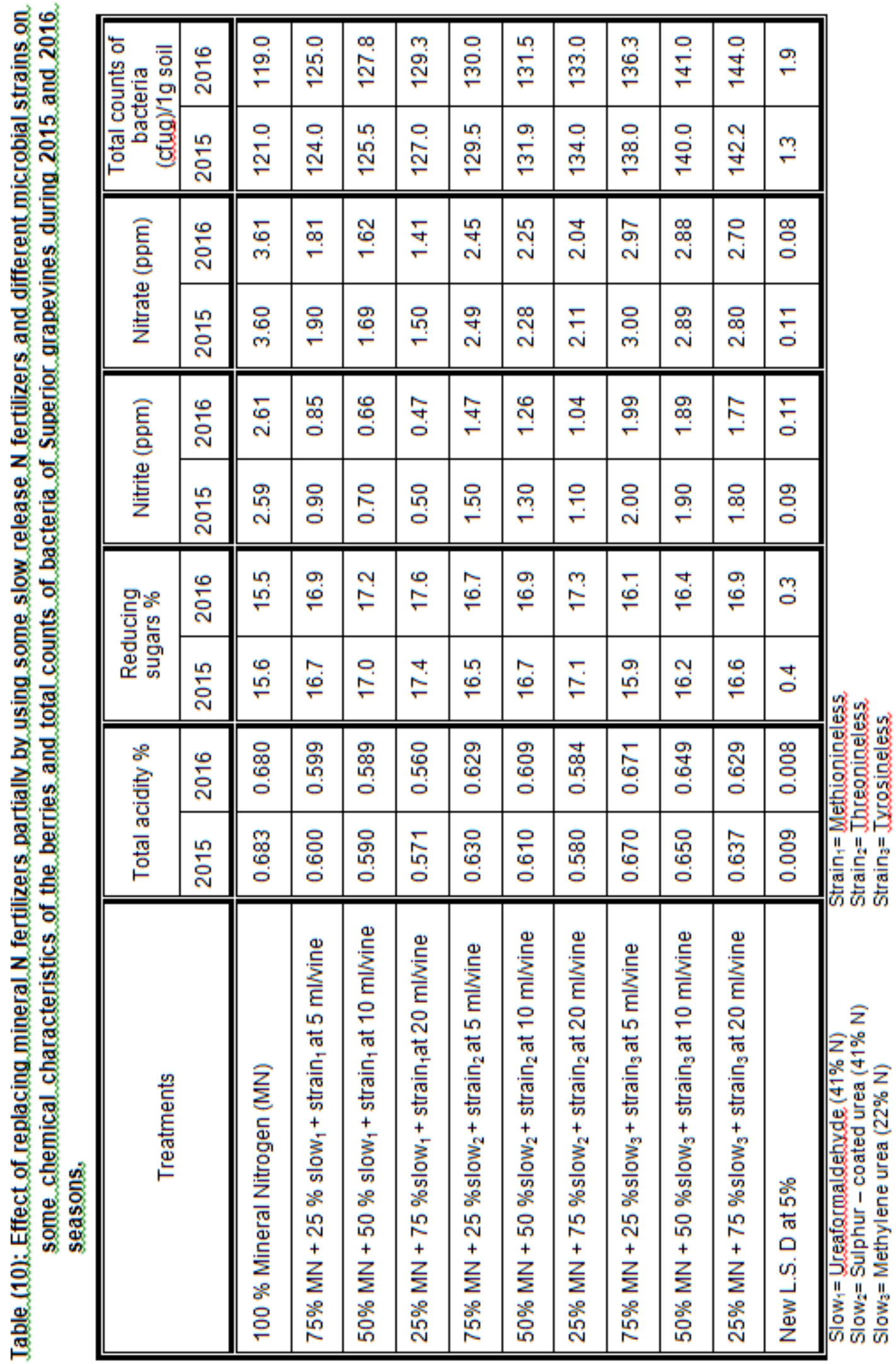


effective in enhancing total counts of becteria in the soil. Subjecting the vines to $\mathrm{N}$ as $25 \% \mathrm{MN}+75 \%$ methylene urea $+20 \mathrm{ml}$ Tyrosineless bacterial strain gave the maximum values (142.2 \& $144.0 \mathrm{CFU} / \mathrm{g}$ soil) during both seasons, respectively. Similar trend was obvious during both seasons.

\section{Economical study for the recommended treatment it applied in one feddan:}

As shown in Table (11) net profit gained by the application of the recommended treatment $(50 \%$ Mineral $\mathrm{N}+50 \%$ methylene urea $+10 \mathrm{ml}$ strain Tyrosineless /vine) it applied in one feddan contains 700 vines reached 7098 (L.E) and 14578 (L.E) while in the control vines (100\% M.N) reached 4720 (L.E) and 7200 (L.E) during both seasons, respectively. The increase on net profit due to application of the recommended treatment over the control reached 2378 (L.E) and 7378 (L.E) during both seasons, respectively

\section{Discussion:}

Azospirillum produces several phytohormones including IAA, gibberellins, cytokinins and ethylene (Bashan and
Holguin, 1997). Plant growth hormones produced by bacteria can increase growth rates and improve yields of host plants (Glick, 1995). IAA production has beneficial effects on the plant - Azospirillum association.

The production of phytohormones by plant growth promoting rhizobacteria is considered to be an important mechanism by which these bacteria promote plant growth.

Slow release fertilizers release their own from nutrients at longer times. The continuous providing of the vines with their requirements from different nutrients can be realized by using these fertilizers. They protect nutrients from fixation, leaching and volatilization (Wang and Alva, 1996).

Organic and biofertilzation when used as a partial replacement of inorganic $\mathrm{N}$ fertilizers were responsible for enhancing $\mathrm{N}$ fixation, organic matter, water retention, availability of nutrients, root development, the biosynthesis of hormones and antibiotics and reducing soil pH (El-Sisy, 2000; Kannaiyan, 2000 and Cabrera et al., 2003).

Table (11): Economical study for the recommended treatment if it applied in one feddan.
\begin{tabular}{|l|c|c|} 
Recommended treatment & 2015 & 2016 \\
Costs Hort. Practices (L.E) & 17000 & 18000 \\
Costs of mineral N (L.E) & 188 & 188 \\
Costs of Methylene urea (L.E) & 400 & 400 \\
Costs of Tyrosineless bio (L.E) & 154 & 154 \\
Total costs (L.E) & 17742 & 18742 \\
Yield/fed (tons) & 6.21 & 8.33 \\
\hline Price of yield/fed & 24840 & 33320 \\
\hline Net profit (L.E) & 7098 & 14578 \\
\hline Control & & 18000 \\
\hline Costs Hort. Practices (L.E) & 17000 & 6.30 \\
\hline Yield/fed (tons) & 5.43 & 25200 \\
\hline Price of yield/fed (L.E) & 21720 & 7200 \\
\hline Net profit (L.E) & 4720 & 7378 \\
\hline Increase over control & 2378 & \\
\hline
\end{tabular}

${ }^{*}$ Price of ton grapes in the first (2015) and second season (2016) were 4000 (L.E). 
The beneficial effect of organic manures in enhancing growth, vine nutritional status of Superior grapevines might be attributed to their important roles on enhancing soil fertility, organic matter, availability of all nutrints as well as the biothensises nutral hormones $\mathrm{B}$ vitamins and antibiotics as well as lowering soil $\mathrm{pH}$ and salinity (Mengel et al., 2001). These results are in agreement with those obtained by (Dakhly et al., 2007; Uwakiem, 2011; Abou El-Lail, 2012; AllamAida et al., 2012; Shaheen et al., 2013; Ahmed et al., 2014; Abd El-Kareem, 2014; El-wany, 2015; Abd El-Reheem, 2015; AlySamar, 2015; Tony, 2016; Ahmed et al., 2017 and El-Kady-Hanaa, 2017).

\section{Conclusion:}

Amending Superior grapevines with $\mathrm{N}$ as $50 \%$ inorganic $\mathrm{N}$ (ammonium nitrate) $+50 \%$ slow release $\mathrm{N}$ fertilizer (methylene urea) + Tyrosineless at $10 \mathrm{ml} / \mathrm{vine}$ was responsible for promoting the yield. Treating the vines with $(25 \% \mathrm{MN}+75 \%$ the slow release $\mathrm{N}$ fertilizer ureaformaldehyde + bacterial strains namely Methionineless at $20 \mathrm{ml} / \mathrm{vine}$ ) gave the best results with regard to berries quality.

\section{REFERENCES}

Abd El- Kareem, A.M. (2014). The beneficial effects of biofertilization and weed control on fruiting of Superior seedless grapevines. Ph. D. Thesis Fac. of Agric. Minia Univ. Egypt.

Abdel-Reheem, A., H. El- Wakeel, A. Abd El- Hamid and A.E. Mansour-Noha (2015). Effect of organic and bioorganic of nitrogen fertilization on growth, yield, fruit quality and nutritional status of Superior grapevines, J. Biol. Chem. Environ, Sci. 10(1): 481-500.

Abou El- Lail, H.H. (2012). Effect of some biofertilizers application on yield and fruit quality of Superior seedless and Red Globe seeded gape cultivars for export. Ph.D. Thesis Fac. Agric. Assiut Univ. Egypt.
Ahmed, F.F. and M. A.M. Abada (2012). Response of Thompson seedless grapevines to some slow release N, P and $\mathrm{K}$ fertilizers. Egypt. J. Agric. Res. 90 (3): 1-16.

Ahmed, F. F. and M. H. Morsy (1999). A new method for measuring leaf area in different fruit crops. Minia of Agric. Res. \& Develop. Vol. (19) pp. 97-105.

Ahmed, F.F., M.A.M. Abada, A.H. Ali and H.M. Allam (2014). Trials for replacing inorganic $\mathrm{N}$ partially in Superior vineyard by using slow release $\mathrm{N}$ fertilizers, humic acid and EM Stem Cell. 5: 16-29.

Ahmed, F.F., F.H. Abd El-Aziz, A.M.K. AbdelAal and H.F. El-Kady-Hanaa (2017). Behaviour of Red Roomy grapevines to application of some organic and biostimulants as a partial alterative to mineral $\mathrm{N}$ fertilizers. J. Biol. Chem. Environ. Sci. 12(1): 577-608.

Ahmed, F.F., A. Rizk- Isis, O.F. Dakhly and M.Kh. Uwakiem (2007). Behaviour of mature Banaty grapevines to soil inoculation with some newly mutants produced From exposing Azotobacter vinelandii to UV. 8th African Crop Science Society Conference, 27-31 October 2007. Minia, Egypt.

Allam- Aida, M. A., F. F. Ahmed, N. N. ElHefnawy, M. A. El- Hewety and H. A. ElKhafagy (2012). Impact of inorganic $N$ and compost enriched with some bacterial strains on fruiting of Superior and Flame seedless grapevines as well as nitrogenase activity in the soil. Minia J. of Agric. Res. \& Develop. Vol. (32) No. 3 pp $115-130$.

Aly-Samar, S.H. (2015). Influence of reducing mineral nitrogen fertilizer partially by using plant compost enriched with spirulina platensis algae on fruiting of Flame seedless grapevines. M.Sc., Thesis. Fac. of Agric. Minia Univ.

Association of Official Agricultural Chemists (2000). Official Methods of Analysis $14^{\text {th }}$ ed. (A.O.A.C.) Benjamin Franldin Station, Washington D.E.U.S.A., pp. 490-510. 
Attia, M.A. (1990). The biochemistry of urea decomposition by soil organisms. Ph.D. Thesis Fac. Agric., Minia Univ., Egypt.

Balo, E., G. Prilezky, I. Happ, M. Kaholomi and L. Vega (1988). Soil improvement and the use of leaf analysis for forecasting nutrient requirements of grapes. Potash Review subject $2^{\text {nd }}$ suite No.6.

Bashan, Y. and G. Holguin (1997). Azospirillum plant relationships. Environmental and Physiological advances. Can J Microbiol, 43: 103-121.

Bouard, J. (1966). Recharches, physiologiques sur la vigen at en particulier sur laoudment des serments. Thesis Sci. Nat. Bardeux France, p.34.

Cabrera, O., J. Valera Garza and J.F. Aguirre Medina (2003). Use of biofertilizers in agricultural crops in the central region of Mexico. Agricultural Tecnica en Mexico Institutro Nacional de Investigaciones Forestales, Agricolasy pecuarias (INIFAP). 2: $213-225$.

Cochran, W. G. (1950): Estimation of bacterial densities by means of the" most probable number". Biometrics, 6(2), 105116.

Dakhly, O.F; Ahmed, F.F.; Rizk- Isis; A. and Uwakiem, M.Kh. (2007): Response of young Banaty grapevines to biofertilization with some mutants produced from Azotobacter vinelandii. $8^{\text {th }}$ African Crop Science Society Conference, 27-31 October 2007. Minia, Egypt.

El- Kady- Hanaa, F.M. (2017). Behaviour of Red Roomy grapevines to application of some organic and biostimulants as a partial alternative to mineral $\mathrm{N}$ fertilizer. Ph.D. Thesis Fac. of Agric. Minia Univ. Egypt.

El-Sisy, I.M.H. (2000). Assessing the pollution caused by excessive nitrogen fertilization. J. Agric. Sci, Mansoura Univ., 25 (11): 7297-7313.

El-Wany, A.R.M. (2015). Response of Thompson seedless grapevines to application of EM and fulvic acid as a partial replacement of inorganic $\mathrm{N}$ fertilizer. M.Sc. Thesis Fac. of Agric. Minia Univ. Egypt.

Fong, K. and R. C. Bockrath (1979). Inhibition of deoxyribonucleic acid repair in Escherichia coli by caffeine and acriflavine after ultraviolet irradiation. Journal of Bacteriology, 139(2), 671-674

Glick, B. R. (1995). The enhancement of plant growth by free-living bacteria. Canadian Journal of Microbiology, 41(2), 109-117.

Gobara, A. A., F. F. Ahmed, M. A. Ragab and M. Kh. Kamel (2003). Effect of Insiabine and Agrolig on growth, yield and fruit quality of Flame seedless grapevines. First Egyptian \& Syrian Conf, 8-11 Dec. Minia Univ. Egypt pp 1-16.

Ibrahim- Asmaa, A. H. (2001). Effect of some slow and fast release nitrogen fertilizers and pinching on yield and quality of Red Roomy grapevines. M. Sc. Thesis Fac. of Agric. Minia Univ. Egypt.

Kannaiyan, S. (2002). Biotechnology of Biofertilizers. Alpha Sci. Inter. Ltd., P.O. Box 4067 Pangbourne R. 68 U.K., pp. 1275

Klingmuller, W. (1982). Preface In: Klingmuller, W (ed) Azospirillum: genetics, physiology, ecology. Spring, Berlin Heidelberg, New York, pp: 5-7.

Lane, J.H. and L. Eynon (1965). Determination of reducing sugars by means of Fehling's solution with methylene blue as indicator A.O.AC. Washington D.C., U.S.A.

Mahendran, P. P. and P. Chandramani (1998): NPK uptake, yield and starch content of potato cv. Kufri Jyoti as influenced by certain bio-fertilizers. Journal of the Indian potato Association, 25(1\&2), 50-52.

Mengel, K.E., E.A. Kirkby, H. Kosegarten and T. Appel (2001). Principles of Plant Nutrition . $5^{\text {th }}$ Ed. Kluwer Academic publishers Dordecht p. 1-311.

Mckenney, D. E. N. I. S. E. and T. H. O. Y. D. Melton (1986). Isolation and characterization of ack and pta mutations 
in Azotobacter vinelandii affecting acetate-glucose diauxie. Journal of bacteriology, 165(1): 6-12.

Pedrosa, F. O. and M. G. Yates (1984). Regulation of nitrogen fixation (nif) genes of Azospirillum brasilense by nifA and ntr (gln) type gene products. FEMS microbiology letters, 23(1): 95-101.

Rangaswamy, R. (1995). Randomized Complete Block Design. In: A Text Book of Agricultural Statistics. New Age International Publishers, pp281-309.

Rao, G.N. (2007). Statistics for Agricultural Sciences. BS Publications.

Ridnour- Lisa, A., E. Sim- Julia, A.H. Michael, A.W. David, M.M. Sean, R.B. Garry and R.S. Douglas (2000). A spectrophotometric Method for the Direct Detection and Quantitation of Nitric Oxide, Nitrite and Nitrate in Cell culture Media. Analytical Biochemistry, 281: 223229

Roberts, G. P. and W. J. Brill (1981). Genetics and regulation of nitrogen fixation. Annual Reviews in Microbiology, 35(1): 207-235.

Santero, E., F. Luque, J. R. Medina and M. Tortolero (1986). Isolation of ntrA-like mutants of Azotobacter vinelandii. Journal of bacteriology, 166(2): 541-544.

Shaaban, A.S.A. (2014). Effect of organic fertilization on growth and quality of Superior grapevines. Ph.D. Thesis Fac. of Agric. Cairo. Univ., Egypt.

Shaheen, M. A., Sahar M. Abd El-Wahab, F.M. El-Morsy and A.S.S. Ahmed (2013). Effect of organic and bio-Fertilizers as a partial substitute for NPK mineral fertilizer on vegetative growth, leaf mineral content, yield and fruit quality of Superior grapevine. Journal of Horticultural Science \& Ornamental Plants 5 (3): 151159.

Smith, F., M.A. Gilles, J.K. Hamlton and P.A. Godees (1956). Colorimetric methods for determination of sugar and related substances. Annals. Chen, 28 : 350-356.

Tony, M.S.S. (2016). Partial replacement of inorganic $\mathrm{N}$ fertilizer in Superior vineyard by using compost enriched with some microorganism. M.Sc. Thesis fac. of Agric. Minia Univ., Egypt.

Uwakiem, M. Kh. (2006). Response of Banaty grapevines to biofertilization with some mutants produced from Azotobacter vinelandii. M.Sc. Thesis fac. of Agric. Minia Univ., Egypt.

Uwakiem, M. Kh. (2011). Effect of some organic, bio and slow release $\mathrm{N}$ fertilizers as well as some antioxidants on vegetative growth, yield and berries quality of Thompson seedless grapevines. Ph. D, Thesis. Fac. of Agric. Minia Univ. Egypt.

Vande Broek, A. and J. Vanderleyden (1995). Review: genetics of the Azospirillum-plant association. CRC Crit. Rev Plant Sci, 5: 445-466.

Von- Wettstein, D.Y. (1975). Chlorophyll lettale under submikroshopische formiueshrel der plastiden celi prp. Trop. Res. Amer. Soc. Hort. Sci. 20pp. 427433.

Wang, F. L. and A. K. Alva (1996). Leaching of nitrogen from slow-release urea sources in sandy soils. Soil Science Society of America Journal, 60(5): 14541458.

Wani, S.P. and K.K. Lee (1995). Microorganisms as biological inputs for sustainable agriculture in organic agriculture, theory and practices (ed.) P.K. Thampan, Peeky Tree Crops Development Foundation, Gandhi NagarCochin 682-220, p.36-67.

Wilde, S. A., R. B. Corey, J. G. Layer and G. K. Voigt (1985). Soils and Plant Analysis for Tree Culture. Mohan Primlani, Oxford \& IBH Publishing Co., New Delhi, India, p 1142. 


\title{
F. F. Ahmed, et al.,
}

\section{تأثثير بعض سلالات الأزوسبيريلام كبديل جزئى للسماد النيتروجينى الغير عضوى علي المحصول وجودة حبات العنب السوييريور}

\author{
فيصل فاضل أحمد(1) ، عمر فتحى داخلى(2) ، محمد علي مجاور عباده(3) ،

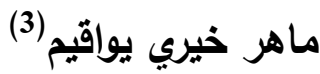

$$
\text { (2) قسم البهاثين - كلية - كلية الزراعة - جامعة المنيا - مصر - جامعة المنيا - مصر }
$$

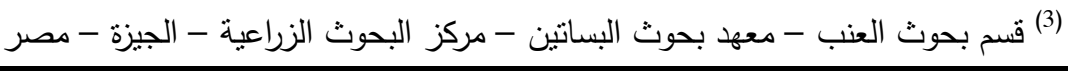 \\ الملخص العربي
}

تم الحصول على 91 طفرة ناتجة من تعريض بكتريا الأزوسبيريلام براسيلنز لتركيزات ومواعيد مختلفة من مطفر

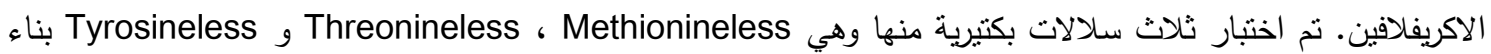

علي قوة النمو علي البيئة الغذائية.

وتم تلقيح كرمات العنب السوبيريور بهذه السلالات البكتيرية بمعدل 5 إلى 20 مل / كرمة وثلاثة أسمدة نيتروجينية بطيئة

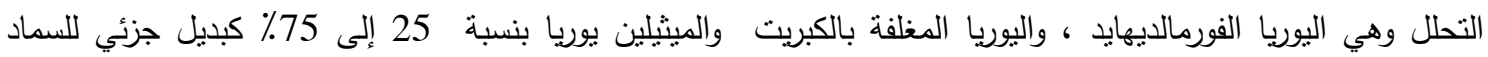
النيتروجينى السريع التحلل وهو نترات الأمونيوم خلال موسمي 2015 و 2016 ولئيا

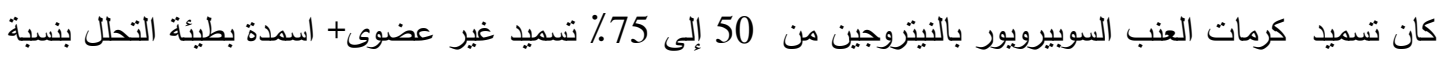

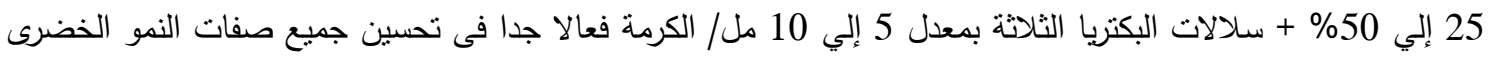

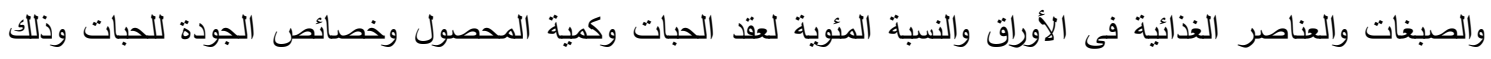

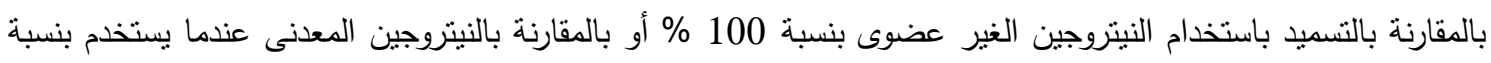
25 \% وكان هناك انخفاض واضح فى محتوى العصير من النترات والنينريت عند نقص النسبة المئوية المستخدمة من بالنيا النيتروجين الغير عضوى من 100 إلي 25 \% كذللك مع زيادة النسبة المئوية المستخدمة من الأسمدة بطيئة التحلل من 25 من 25 من

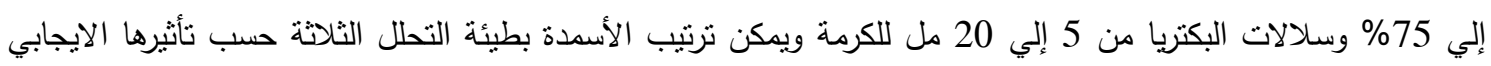

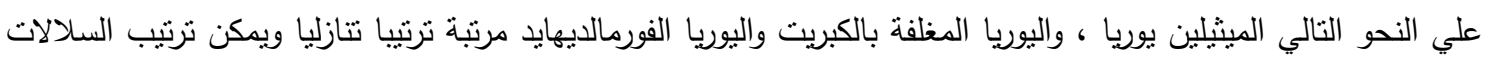

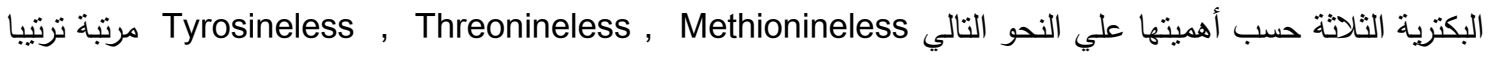
تصاعديا. توصى الدراسة بتسميد كرمات العنب السوبيريور بالنيتروجين بنسبة 50 \% تسميد نيتروجينى غير عضوى (فى صورة

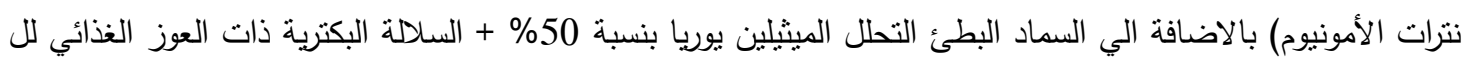

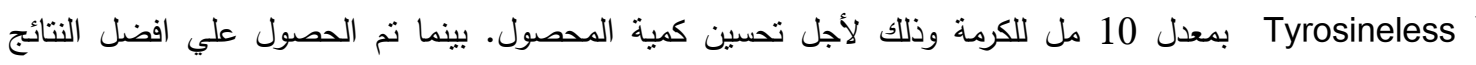

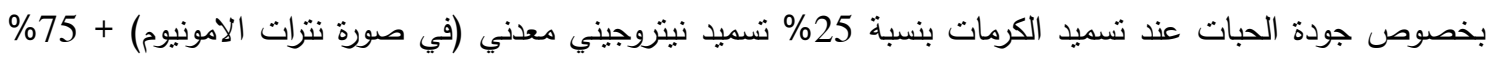

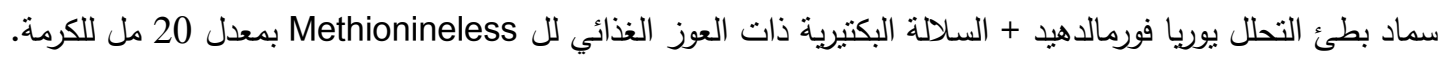
الكلمات الدالة: الأسمدة النيتروجينية السريعة والبطيئة التحلل - السلالات البكترية - النمو - كمية المحصول - خصائص الجودة - العنب السوبيريور . 